\title{
Degradation by a Pyrene-Assimilating Bacterium of Polycyclic Aromatic Hydrocarbons in Heavy Oil Leaked from a Wrecked Tanker
}

\author{
Shigeru Mineki ${ }^{* 1}$, Fumio Sugawara ${ }^{* 1}$, Masaru Matsuo ${ }^{* 2}$, \\ Iwao UCHIY AMA ${ }^{* 3}$, and Sumio GoTo*3
}

\author{
*1 Department of Applied Biological Science, Science University of Tokyo \\ (2641 Yamazaki, Noda-shi, Chiba-ken 278-8510) \\ *2 Institute of Applied Biochemistry, Tsukuba University \\ (1-1-1, Tennoodai, Tsukuba-shi, Ibaragi-ken 305-8572) \\ *3 Department of Community Environmental Sciences, National Instite of Public Health \\ (4-6-1, Shirokanedai, Minato-ku, Tokyo 108-8638)
}

\begin{abstract}
Benz(a)anthracene(BaA), pyrene, benzo(a)pyrene(BaP), and benzo(ghi)perylene in heavy oil that had washed ashore, after leaking from a wrecked Russian oil tanker, the Nakhodka, disappeared by $99 \%, 92 \%, 60 \%$ and $33 \%$, respectively, through the action of Mycobacterium sp. $\mathrm{H} 2-5$ at $30^{\circ} \mathrm{C}$ over a period of 20 days. This bacterium had been initially isolated as a pyrene-assimilating bacterium in 1994. PAHs in commercial heavy oil (class C) disappeared by $92 \%, 99 \%, 60 \%$, and $10 \%$, respectively, by the bacterium under the same conditions. The disappearance of PAHs in the two heavy oil samples by strain $\mathrm{H} 2-5$ was essentially to the same extent. The bacterium thus prevented any damage from the drifting of heavy oil.
\end{abstract}

Key words : degradation of polycyclic aromatic hydrocarbons, heavy oil, pyrene-assimilating bacteria, pyrene, benzo(a)pyrene, benz(a)anthracene, benzo(ghi)perylene

\section{Introduction}

Energy consumption is considered to be increasing with the development of industries today, and the greenhouse effect by carbon dioxide, nitrous oxide, methane, and so on, has been a serious worldwide problem. Transit of crude oil and its related oils as the main energy source of industries has been properly increased, yet pollution of coasts with spilled oil by accidents of oil tankers has repeatedly occurred. Such pollution is considered to damage the ecosystem of the site, and consume a long-term period to recover it. That is to say, polycyclic aromatic hydrocarbons (PAHs), which are natural constituents of fossil fuels ${ }^{1), 2)}$, are a class of potentially carcinogenic chemicals in the environment in addition to mycotoxins and nitrosoamines. The degradation of high-molecular-weight(HMW) $\mathrm{PAHs}^{3), 4)}$, containing four or more benzene rings, by microorganisms is generally more difficult than that of lower-molecular-weight (LMW) PAHs, such as naphthalene, anthracene, and phenanthrene ${ }^{5), 6)}$. Therefore, remediation of sites contaminated with HMW PAHs is very crucial as a countermeasure against these environmental carcinogens. Although degradation of $n$-alkanes and LMW PAHs by a variety of bacteria has been demonstrated, investigation of biodegradation of HMW PAHs remains scarce. Mycobacterium sp. H2-5, which was isolated as a pyrene-assimilating bacterium in 19947), degraded PAHs in extract from airborne particles and in extract (tarry matter) from soil ${ }^{8}$.

In this study, we describe the disappearance of several HMW PAHs in heavy oil that washed ashore at Mikuni-cho in Fukui Prefecture, which spilled from the wrecked Russian

Corresponding author: Shigera MINEKI 
oil tanker Nakhodka on Jan. 2, 1997, by Mycobacterium sp. H2-5.

\section{Experimental}

\subsection{Materials}

Heavy oil that washed ashore was collected at Echizenmatsushima, Mikuni-cho in Fukui Prefecture on Jan. 16, 1997. As standard for PAHs, pyrene, benz(a)anthracene (BaA), and benzo(a)pyrene $(\mathrm{BaP})$ were purchased from Wako Pure Chem. Ind., Ltd., and benzo(ghi)perylene (BghiP) was purchased from Aldrich Chem. Co. Inc. Fluorometry grade reagents and HPLC grade reagents were used for extraction of PAHs and for HPLC analyses, respectively, without further purification. Other reagents were of GR-grade and were used as received.

\section{$2 \cdot 2$ Media}

For a complete medium, TSB medium was used; it contained $30 \mathrm{~g}$ of Tryptic soy broth (Difco) per 1 liter of distilled water; $\mathrm{pH}$ 7.0. The mineral salt medium (MM) used for enrichment and culturing of pyrene-degrading bacteria contained, per liter, $1 \mathrm{~g}$ of $\mathrm{Na}_{2} \mathrm{HPO}_{4}$. $12 \mathrm{H}_{2} \mathrm{O}, 0.5 \mathrm{~g}$ of $\mathrm{KH}_{2} \mathrm{PO}_{4}, 1.5 \mathrm{~g}$ of $\left(\mathrm{NH}_{4}\right)_{2} \mathrm{SO}_{4}, 1 \mathrm{~g}$ of $\mathrm{NH}_{4} \mathrm{Cl}, 0.5 \mathrm{~g}$ of $\mathrm{MgSO}_{4} \cdot 7 \mathrm{H}_{2} \mathrm{O}, 0.5 \mathrm{~g}$ of $\mathrm{NaCl}, 0.015 \mathrm{~g}$ of $\mathrm{CaCl}_{2} \cdot 2 \mathrm{H}_{2} \mathrm{O}, 0.01 \mathrm{~g}$ of $\mathrm{FeCl}_{3} \cdot 6 \mathrm{H}_{2} \mathrm{O}$; the $\mathrm{pH}$ was adjusted to 7.0. As a carbon source, $0.02 \mathrm{ml}$ of pyrene solution $(20 \mathrm{mg} / \mathrm{ml}$ dimethylformamide (DMFA)) was added to $10 \mathrm{ml}$ of $\mathrm{MM}$ (pyrene-MM) in an L-tube $(\phi 18 \mathrm{~mm} \times 120 \mathrm{~mm})$.

\section{$2 \cdot 3$ Cultivation of bacteria}

After strain $\mathrm{H} 2-5$ was cultured in an L-tube containing $10 \mathrm{ml}$ of TSB medium on a reciprocal shaker $\left(100\right.$ strokes $/ \mathrm{min}$ ) at $30^{\circ} \mathrm{C}$ for one month, $5 \mathrm{ml}$ of the culture was inoculated to $250 \mathrm{ml}$ of $\mathrm{MM}$ containing $2.5 \mathrm{ml}$ of the pyrene solution (DMFA) in a $500-\mathrm{ml}$ of Erlenmeyer flask, and then incubated on a rotary shaker $(160 \mathrm{rpm})$ at $30^{\circ} \mathrm{C}$. Growth of strain $\mathrm{H} 2-5$ was evaluated by measuring the protein of filter cake of the culture broth by the method of Lowry et al. The culture was harvested at the stationary phase (after 30 days) by centrifugation and the pellet was washed with $\mathrm{MM}$, and used in subsequent investigations.

\subsection{Degradation of PAHs in the heavy oil}

After the heavy oil solution $(0.1 \mathrm{mg} / 0.3 \mathrm{ml}$ benzene) was added to the $\mathrm{L}$-tube, which held 30 glass beads $(\phi 30 \mathrm{~mm})$, it was shaken gently, and then the solvent was evaporated under reduced pressure. The cell solution $(0.8 \mathrm{mg}$ dry-cell weight $/ 5 \mathrm{ml})$ and $5 \mathrm{ml}$ of $\mathrm{MM}$ were added to the L-tube, followed by incubation on a reciprocal shaker $\left(100 \mathrm{strokes} / \mathrm{min}\right.$ at $\left.30^{\circ} \mathrm{C}\right)$.

\subsection{Extraction of PAHs}

The extraction of PAHs was done by modifying the method of Takagi et al. ${ }^{9}$ The culture was extracted with $20 \mathrm{ml}$ of cyclohexane in a screw-topped test tube by shaking vigorously, and the organic layer was collected and concentrated down to $1 \mathrm{ml}$ under nitrogen stream. PAHs in the concentrate were extracted with $0.5 \mathrm{ml}$ of dimethyl sulfoxide and analyzed by HPLC.

\subsection{Analyses of PAHs}

The concentrations of PAHs were measured spectrophotometrically ${ }^{10)}$. Namely, the intensity of fluorescence of each sample was measured by a Hitachi 850 fluorescence spectrophotometer, to determine the relative concentration with a control (pyrene: Excitation, $339 \mathrm{~nm}$, Emission, $373 \mathrm{~nm}$; BaA: $292 \mathrm{~nm}, 412 \mathrm{~nm}$; BaP: $370 \mathrm{~nm}, 406 \mathrm{~nm}$; BghiP: $370 \mathrm{~nm}, 406 \mathrm{~nm}$ ). $\mathrm{PAHs}$ extracted from the heavy oils were separated into individual PAHs by Shimadzu LC-6A HPLC using ODS-60-5 double columns $(4.6 \times 30 \mathrm{~mm}$ for concentration, and $4.6 \times 250$ $\mathrm{mm}$ for separation, Tokyo Chemical Industry, Tokyo, Japan). After the application of the sample solution, PAHs were concentrated by a first column with a mixed solution of acetonitrile $(\mathrm{AN}) / \mathrm{H}_{2} \mathrm{O}=1: 1$ for $5 \mathrm{~min}$, and then they were separated by a second column with $\mathrm{AN} / \mathrm{H}_{2} \mathrm{O}=4: 1$. 


\section{Results and Discussion}

\subsection{Disappearance of PAHs in the commercial heavy oil (Class C)}

The commercial heavy oils (Class C) have a variety of PAH compositions, and these differences depend on the district. The heavy oil samples used in this study mainly contained pyrene, BaA, BaP, and BghiP as PAHs (Table 1). As shown in Fig. 1(A), strain H2-5 strongly degraded pyrene, and it almost disappeared (99\% decrease against the control) after incubation for 5 days. $\mathrm{BaA}$ and $\mathrm{BaP}$ also disappeared at levels of $92 \%$ and $60 \%$, respectively, by strain $\mathrm{H} 2-5$ after incubation for 20 days. On the other hand, BghiP hardly disappeared under the same condition. This result may be due to the structural difference that BghiP has more aromatic rings (6 rings) as compared with the former 3 PAHs, which have 4 or 5 rings.

\subsection{Disappearance of PAHs in the heavy oil that drifted ashore}

The heavy oil that drifted ashore contained the same PAHs as the commercial heavy oil, but two heavy oils differed much on the pyrene and BaA contents (Table 1). As shown in Fig. 1(B), pyrene disappeared rapidly (92\% after 20 days) as was seen in the commmercial

Table 1 Polycyclic Aromatic Hydrocarbon Contents in Two Heavy Oil Samples.

\begin{tabular}{lcc}
\hline PAH & Com-HO & HO-WA $^{b}$ \\
\hline Pyrene & 63.8 & 12.6 \\
BaA & 9.6 & 20.2 \\
BaP & 6.3 & 4.0 \\
BghiP & 25.6 & 26.2 \\
\hline
\end{tabular}

$\mathrm{ng} / 0.1 \mathrm{mg}$ oil/L-tube.

${ }^{a}$ Commercial heavy oil (Class C).

${ }^{b}$ Heavy oil that washed ashore.
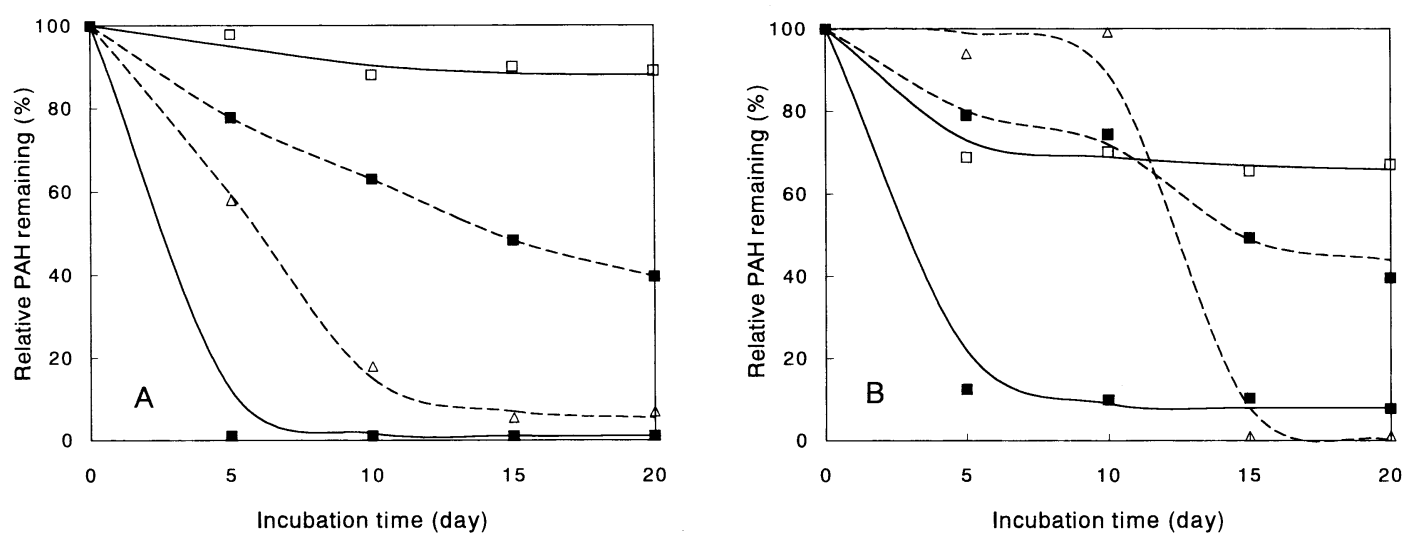

Fig. 1 Disappearance of PAHs in Two Heavy Oil Samples by Strain H 2-5.

A : Commercial heavy oil (Class C) ; B : Heavy oil that washed ashore ;

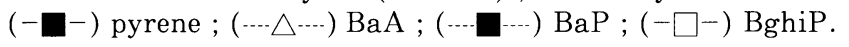

heavy oil. Although BaA did not disappear with 10 days treatment, subsequently it was abruptly degraded and decreased to be undetected after 15 days. This phenomenon may be due to the high content of $\mathrm{BaA}$ in the heavy oil that washed ashore. Disappearances of BaPs in both heavy oils were almost the same degree (60\% after 20 days). BghiP was not well degraded (33\%) even after 20 days, but this value was 3 -fold higher than that of commercial heavy oil. The cause of this difference is not clear at present. Further investigations are nec- 
essary including the effect of interaction of PAHs. Negative effects of sea water and photochemical products by drifting on the degradation of PAHs in the heavy oil by strain $\mathrm{H} 2-5$ had been feared, but there was no great negative effect in those results. Therefore, no harm was done by the drifting of heavy oil for two weeks, to the activity of the bacterium. But a possibility that PAHs change to compounds that are more resistant to the bacterial degradation, or that inhibitory compounds are produced after longer-term drifting, cannot be neglected. In our previous work $\left.{ }^{8}\right), \mathrm{BaA}$ did not disappear individually as much as in the results of this study; therfore, a certain compound in the heavy oil thought to facilitate the degradation of $\mathrm{BaA}$, i. e., cooxidation ${ }^{5)}$ with it, may be present.

In our other study ${ }^{11)}$, mutagenicity of the extract by methanol from the heavy oil that drifted ashore was $230,000 \mathrm{rev} / \mathrm{g}$, which was $3^{-}$to 4 -fold higher than the values for the extracts from the soil samples at urban areas in Tokyo in 1984 and 1996. Since a respectable amount of the heavy oil was thought to filter into the sand of the coast, its effect on the ecosystem there must be watched.

\section{Acknowledgments}

We are grateful to Dr. K. Hayakawa and Dr. M. Tanaka in Kanazawa University for sampling the heavy oil that washed ashore. This study was partially supported by a Grant-inAid for Scientific Research (C; No. 10680553) from the Ministry of Education, Science, Sports and Culture of Japan.

(Raeceived Jun. 11, 1998 ; Accepted Sept. 28, 1998)

\section{References}

1) H. Matsushita, Nenryou Kyoukaishi, 51, 25 (1972).

2) L. Attias, A.R. Bucchi, F. Maranghi, S. Holt, I. Marcello, G.A. Zapponi, Centr. Eur. J. Publ. Hlth, 3, 142 (1995).

3) M.A. Heitkamp, W. Franklin, C.E. Cerniglia, Appl. Environ. Microbiol., 54, 2549 (1988).

4) J.G. Mueller, P.J. Chapman, B.O. Blattmann, P.H. Pritchard, Appl. Environ. Microbiol., 56, 1079 (1990).

5) E. McKenna, "Biodegradation of Polynuclear Aromatic Hydrocarbon Pollutants by Soil and Water Microorganisms", Final Report, Project No. A-073-ILL, University of Illinois, Water Resources Center, Urbana (1976) p. I-11.

6) D.T. Gibson, V. Sabramanian, "Microbial Degradation of Aromatic Hydrocarbons", D.T. Gibson (Ed.), Marcel Dekker, New York (1984) p. 181.

7) S. Mineki, K. Sugita, S. Goto, I. Watanabe, T. Mizoguchi, T. Ishii, M. Iida, J. Environ. Chem., 4, 813 (1994).

8) S. Mineki, K. Sugita, S. Goto, I. Watanabe, T. Mizoguchi, T. Ishii, M. Iida, Policyclic Aromatic Compounds, 11, 115 (1996).

9) Y. Takagi, O. Endo, S. Goto, A. Kawai, M. Murata, H. Matsusita, J. Japan Soc. Air Pollut., 21, 312 (1986).

10) K. Tanabe, C.T.Kuo, S. Imamiya, H. Matsushita, J. Japan Soc. Air Pollut., 22, 334 (1987).

11) S. Goto, S. Mineki, K. Sugita, O. Endo, R. Murayama, I. Uchiyama, M. Tanaka, K. Hayakawa, J. Environ. Chem., 7, 553 (1997). 


\section{[ノート］＼cjkstart座礁タンカーからの流出重油に含まれる \\ 多環芳香族炭化水素のピレン資 \\ 化性細菌による分解}

峯木 茂*1 ・菅原二三男*1 ・松尾勝*2 $・$ 内山 巌雄 ${ }^{* 3} \cdot$ 後藤 純雄 ${ }^{* 3}$

*1 東京理科大学理工学部応用生物科学科（开278-8510 千葉県野田市山崎 2641）

$* 2$ 筑波大学応用生物化学系 (干 $305-8572$ 茨城県つくば市天王台 1-1-1)

*3 国立公衆衛生院地域環境衛生学部（テ108-8638 東京都港区白金台 4-6-1）

座礁したロシアのタンカーナホトカ号の漂着重油中のベンツ (a) アントラセン $(\mathrm{BaA})$, ピレン, ベンゾ $(\mathrm{a})$ ピ レン (BaP)，そして，ベンゾ（ghi）ペリレン (BghiP) は, 1994 年にピレン資化性細菌として分離された Mycobacterium sp. H 2-5 株によって, $30^{\circ} \mathrm{C}, 20$ 日の処理で, それぞれ, 99\%, 92\%, 60\%, そして, 33\% 減少し た。同条件のもとで市販の C 重油中の各 PAH の減少は，それぞれ，92\%，99\%，60\%，そして，10\%であった。 両重油試料のあいだでは，H 2-5 株による各 PAH の減少に大きな差は認められなかった。

(連絡者: 峯木 茂) Vol. 47, No. 12, 1351 (1998)

\section{$[$ ノート] \\ アタパルジャイトとセピオライトへの \\ トリオレインの吸着状態 \\ 伊内 秋夫*1 ・坊木 佳人*2 \\ *1 徳島大学医学部 (宁770-0042 徳島市蔵本町 3-18-15) \\ $* 2$ 近畿大学薬学部 (干577-0818 東大阪市小若江 3-4-1)}

アタパルジャイトとセピオライトを用い，一定量の $\beta$ 一カロチンを含むトリオレイン溶液からのトリオレインの 吸着について検討した。トリオレインの吸着等温線はラングミュアー式に良く適合した。邽カロチン・トリオレ イン溶液からのトリオレインの吸着係数 $b$ はトリオレイン溶液からの吸着係数より大きかった。この結果から, 一部のトリオレインは $\beta$-カロチンによって部分的にあるいは全体的に覆われた状態で吸着していることが分かっ た。

（連絡者：坊木佳人）Vol. 47, No. 12, 1355 (1998) 